\title{
Omental infarkt: Olgu sunumu
}

\author{
Omental Infarction: A case report
}

\author{
(D) Ahmet YALNIZ , (D Mesut SEZIKLi², (D Burcu ÇiLEK ${ }^{3}$, (D Ali Alparslan UYAR ${ }^{3}$ \\ Derince Eğitim ve Araştırma Hastanesi, ${ }^{1}$ Radyoloji Kliniği, ${ }^{2}$ Gastroenteroloji Kliniği, ${ }^{3}$ Dahiliye Kliniği, Kocaeli
}

\begin{abstract}
Omental enfarktüsü, omentum majusun perfüzyonunun bozulmasına bağı olarak akut karını taklit eden nadir bir patolojidir. Hastalığın ayırıc tanısında akut kolesistit, akut apandisit, akut divertikülit, renal kolik, kolon perforasyonu düşünülmelidir. Yedi gündür sağ üst kadran ağrsı şikayeti ile başvuran 52 yaşında kadın hastayı sunuyoruz. Abdomen bilgisayarlı tomografi incelemesinde, karaciğer sağ anterior sınırında omentumun sağ ve sağ tarafinda heterojenite ile karakterize bir kitle görünümü ve yoğunluğunda bir artış gösteren hastanın konservatif tedavi ile iki günün sonunda karın ağrısı önemli ölçüde azaldı. Özet olarak, omental infarktüs, akut sağ taraflı abdominal ağrı için ayırıcı tanı olarak düşünülmelidir.
\end{abstract}

Anahtar kelimeler: Omentum, infarktüs

\section{Gíriş}

Omental infarkt, omentum majusun perfüzyonunun bozulması sonucu gelişen, klinik bulgularıla birçok akut karını taklit edebilen, nadir görülen bir patolojidir (1). Klinik ayırıc tanıda akut kolesistit, akut apandisit, akut divertikülit, renal kolik, kolon perforasyonu gibi acil cerrahi girişim gerektirebilecek durumların yer aldığı dışlama tanısıdır (2). Omental infarkt, en sık dördüncü-beşinci dekadlarda görülür. Erkek-kadın oranı 2:1'dir. Olguların sadece \%15'i pediatrik yaş grubundadır. Hastaların çoğu obezdir (3). Omental infarktın doğal patolojik seyri inflamatuvar sürecin retraksiyon, fibrozis ve son olarak da komplet rezolüsyon veya otoampütasyon şeklinde sonlanmasıdır (4). Omental infarktın karakteristik sonografik ve bilgisayarlı tomografi (BT) bulguları literatürde net olarak tanımlanmıştır. BT ile kolayca tanısı konabilecek bir durum olmasına rağmen hastaların farklı tanılarla ameliyat edilirken tanı almaları sık görülür. Olguların çoğu konservatif olarak tedavi edilebildiğinden radyologların da yardımıyla omental infarkt tanııının ameliyat öncesi kesinleştirilmesi gereksiz cerrahi girişimleri engelleyebilmektedir (2). Bu yazıda BT bulguları ile omental infarkt tanısı almış olgu sunulmuştur.

Iletişim: Mesut SEZIKLI

Hitit Üniversitesi Çorum Erol Olçok Eğitim Araştırma Hastanesi, Çorum

E-mail: drsezikli@hotmail.com
Omental infarction is a rare condition that mimics an acute abdomen due to the deterioration in the perfusion of the greater omentum. The differential diagnoses of acute cholecystitis, acute appendicitis, acute diverticulitis, renal colic, and colon perforation should be considered. We present the case of a 52 year old woman who presented with right-sided anterior abdominal pain for 7 days. An abdominal computerized tomography examination showed a mass appearance characterized by increased density and heterogeneity in the right and right side of the omentum in the right anterior border of the liver. After 2 days of conservative treatment, the abdominal pain had significantly reduced. In summary, omental infarction should be considered in the differential diagnosis for acute right-sided abdominal pain.

Key words: Omentum, infarction

\section{OLGU SUNUMU}

Elli iki yaşında, 102 kilogram ağırlığında kadın hasta, yaklaşık bir hafta önce başlayan, şiddeti giderek artan, parasetamolle ağrısı azalmayan sağ üst kadran ağrısı yakınmasıyla gastroenteroloji polikliniğine başvurdu. Ağrı hareketle artan karakterde idi, gıda tüketimi ile ilişkisi yoktu. Hastanın özgeçmişinde tip-2 diyabetes mellitus, altı aydır devam devam eden mide şikayetleri nedeni ile proton pompa inhibitörü kullanımı vardı. Geçirilmiş cerrahi girişimi yoktu. Fizik muayenede sağ üst kadranda hassasiyet, defans ve rebound mevcuttu. Yapılan laboratuvar incelemelerinde beyaz küre sayısl: $8,2 \times 10^{3} \mathrm{u} / \mathrm{L}(3,7-$ 10,4 103 u/L), C-reaktif protein: $93,4 \mathrm{mg} / \mathrm{dl}(0-3,5 \mathrm{mg} /$ $\mathrm{dl})$, sedimentasyon: $74 \mathrm{~mm} / \mathrm{saat}(0-25 \mathrm{~mm} / \mathrm{saat})$, alanin aminotransferaz: $16 \mathrm{U} / \mathrm{L}(0-45 \mathrm{U} / \mathrm{L})$, aspartat aminotransferaz: $17 \mathrm{U} / \mathrm{L}(0-35 \mathrm{U} / \mathrm{L})$, gama glutamil transferaz: 22 $\mathrm{U} / \mathrm{L}(9-36 \mathrm{U} / \mathrm{L})$, alkalen fosfataz: $86 \mathrm{U} / \mathrm{L}(40-150 \mathrm{U} / \mathrm{L})$, total bilüribin: $0,74 \mathrm{mg} / \mathrm{dl}(0,2-1,2 \mathrm{mg} / \mathrm{dl})$, direkt bilüribin: $0,28 \mathrm{mg} / \mathrm{dl}(0-0,5 \mathrm{mg} / \mathrm{dl})$ idi ve diğer tetkikler de normal olarak saptandı. Yapılan batın ultrasonografi (USG) incelemede batın sağ üst kadranda karaciğer anterior komşuluğunda yağlı dokuda inflamasyonla uyumlu heterojenite mevcuttu, ilave patolojik bulgu saptanmadı. Oral ve intravenöz kontrast madde verilerek yapılan abdominal BT incelemede; karaciğer sağ lob anterior komşuluğunda, 
omentum sağında inflamasyonla uyumlu heterojenite ve dansite artı̧ı ile karakterize kitlesel görünüm izlenmekteydi. Tanımlanan bulgulara ilave olarak lezyon içerisinde belirginleşmiş venöz yapılara ait olarak değerlendirilen lineer dansiteler izlenmekteydi.

Sağ üst kadran ağrısı nedeniyle tetkik edilen 40 yaşında kadın hastanın aksiyel (Resim 1-A) ve koronal (Resim 1-B) kontrastlı batın BT incelemesinde karaciğer sağ lob anterior komşuluğunda, omentum sağında inflamasyonla uyumlu heterojenite ve dansite artışı ile karakterize kitlesel görünüm izlenmekteydi. Tanımlanan bulgulara ilave olarak lezyon içerisinde belirginleşmiş venöz yapılara ait olarak değerlendirilen lineer dansiteler mevcuttu.
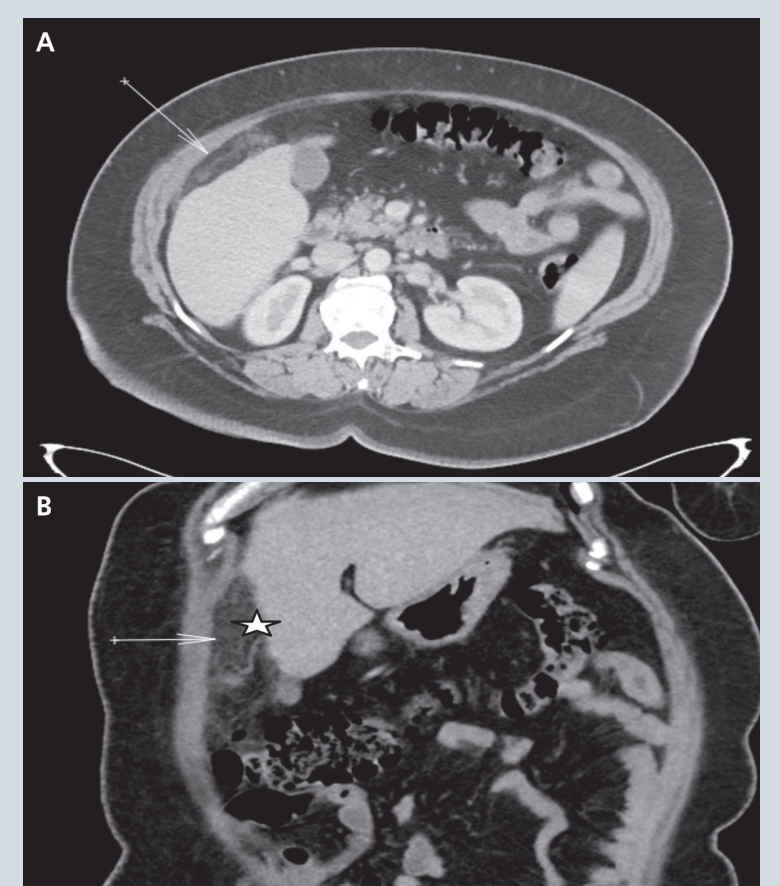

Resim 1. Aksiyel (Resim 1-A) ve koronal (Resim 1-B) kontrastlı batın BT incelemesinde karaciğer sağ lob anterior komşuluğunda, omentum sağında inflamasyonla uyumlu heterojenite ve dansite artışı ile karakterize kitlesel görünüm (oklar) ve lezyon içerisinde belirginleşmiş venöz yapılara ait lineer dansiteler (yıldız).

\section{TARTIŞMA}

Omental infarkt, omentum majusun perfüzyonunun bozulması sonucu gelişen, klinik bulgularıla birçok akut karını taklit edebilen, nadir görülen bir patolojidir. Kesitsel tanı yöntemlerinin kullanılmaya başlanmasıyla bilindiğinden daha sık görülen bir patoloji olduğu anlaşıııı̧ıı (1). Omentum infarktı Leitner ve arkadaşları tarafından iki kategoride sınıflandırımıştır. Her iki tipte de infarkt büyük omentumun torsiyonunun yokluğunda ve varlığında meydana gelebilir. İnfarktus; venöz staz, tromboz, hemorajik nekrozdan sonra venöz tıkanıklık, hemoraji ve yağ hücresi nekrozu nedenli olabilir. Birincil omental infarktüs herhangi bir acil etiyoloji olmaksızın spontan olarak ortaya çıkar ve sonuç olarak büyük omentumun idiyopatik segmental infarktüsü olarak adlandırımıştır. Malformasyon, yağ dağılımındaki lokal varyasyonlar ve artmış omental venler gibi omental varyasyonlar tanıyı buna yönlendirir. Lokal travma, aşırı egzersiz ve öksürüğe sekonder artmış intrabdominal basıncı takiben karaciğer ve abdominal duvar arasındaki büyük omentumun sıkıştııımasıyla torsiyon ve buna müteakip infarktüsün tetiklenebileceği hipotezine sahiptir. Sekonder omentum infarktı, omentum ve patolojik odaklar arasında adezyonlara neden olan neoplazmlar ve inflamatuvar durumlar gibi tanımlanabilir bir nedene sahiptir (5).

Omental infarkt en sık dördüncü ve beşinci dekatlarda görülür. Erkek/kadın oranı 2:1'dir. Hastaların \%15'i pediatrik yaş grubundadır. Hastaların çoğu obezdir (6). Obezite bilinen bir risk faktörüdür. Hipotez, yağlı omentumun kendi distal arteriyel dallarını tıkayabileceğidir (4). Bunun aksine sağlıklı maraton koşucularında düşük omental kan akımı ve fizyolojik şantlanmanın infarktüs riskini artıırdığını öne süren olgu raporları vardır (7). Bizim olgumuzda da hasta literatüre uyumlu olarak beşinci dekatta ve obezdi.

Klinik bulguları nonspesifiktir. Hastalar genellikle ani başlangıçlı, sağda lokalize, şiddeti gittikçe artan karın ağrısı ile başvurur (1). Bulantı ve kusma gibi belirtiler genellikle yoktur. Fizik muayene bulguları değişken olmakla birlikte genellikle, sağ alt ve üst kadran ağrısı görülür (2). Hafif ateş ve lökositoz görülebilir. Bachar ve arkadaşlarının çalışmasında segmental omental infarkt nedeniyle değerlendirilen altı hastanın üçünde lökositozun eşlik ettiği, hastaların hiç birinde ateş olmadığı görülmüştür (8). Bizim olgumuzda da ağrı giderek şiddeti artan sağ üst kadran şeklindeydi ancak bulantı, kusma, ateş ve lökositoz eşlik etmiyordu.

Ayırıcı tanıda; renal kolik, akut kolesistit, akut apandisit, divertikülit düşünülebilir (2). Kadınlarda jinekolojik farklıIıklar, over kist rüptürü ve ektopik gebelik de düşünülmeli$\operatorname{dir}(5)$. Hastalar çoğu kez akut apandisit nedenli cerrahiye alındığında tanı genellikle operasyon sırasında konur (1). USG ve BT bulguları tipiktir (6). USG incelemede maksimum hassasiyet olan bölgede, karın ön duvarının hemen altında, komprese edilemeyen, oval şekilli, büyük, hiperekoik solid kitle lezyonu saptanır. BT'de ise; parietal peritonun hemen altında, çizgisel dansiteler içeren, yoğunluğu yağ dokusuna göre yüksek, kitle etkisine yol açan lezyon izlenir. Olgumuzda BT ile görüntülemede; karaciğer sağ lob anterior komşuluğunda omentum sağında inflamasyonla uyumlu heterojenite ve dansite artışı ile karakterize kitlesel görünüm izlenmekteydi (Resim 1). Benzer bulgu- 
lar epiploik apendajitte de izlenebilir. Kitleyi çevreleyen, viseral peritonun kalınlaşmasına bağlı hiperdens halka ("ring sign") oldukça tipiktir. Lezyon içerisinde, tromboze damarlar veya hemorajik değişikliklere ait hiperdens noktalar saptanabilir. Boyutları genellikle küçüktür $(1,9)$. Olgumuzda da lezyon içerisinde belirginleşmiş venöz yapılara ait olarak değerlendirilen lineer dansiteler izlenmekteydi (Resim 2). Tipik yerleşim, boyut ve görünüm ("ring sign"-heterojen kitle) ile bu iki patoloji çoğunlukla birbirinden ayırt edilebilir. Bazı yazarlar epiploik apendajit ve omental infarktın patofizyolojisi, prognozu ve tedavisinin benzer olduğunu öne sürerek bu iki patolojiyi "intraabdominal fokal yağ infarktı" olarak isimlendirmekte ve ayrımın aslında gereksiz olduğunu savunmaktadırlar $(1,9)$.

Omental infarkt patolojik olarak retraksiyon, fibrozis ve rezolüsyon şeklinde seyreder. Geç komplikasyonlar olarak apse, sepsis izlenebilir. Klinisyenler arasında cerrahi veya konservatif tedaviyi tercih eden iki ayrı görüş vardır. Cerrahi tedavi daha hızlı iyileşme ve ağrı kontrolü sağlamakta ayrıca nekrotik alanın uzaklaştıııması nedeniyle apse oluşumu ve bağırsak tıkanıkığı daha az görülmektedir.
Diğer görüş ise analjeziklerle konservatif yaklaşımın yeterli olacağıdır (2). Konsevatif tedavi; komorbiditeler nedeniyle operatif olmayan hastalar için uygun bir seçenek olmaya devam etmektedir (5). Baachar ve arkadaşları altı hastanın beşinde; Puylaert ise yedi hastadan oluşan serisinde tüm hastalarda konservatif tedavi ile semptomların tamamen kaybolduğunu bildirmiştir $(8,10)$.

Biz de hastamızda konservatif tedaviyi tercih ettik. Konservatif tedavi ile iki gün sonunda ağrısı belirgin derecede azalan hasta, bir ay sonra kontrole gelmek üzere taburcu edildi. Bir ay sonraki klinik değerlendirmede; hastanın ağrısının tamamen geçtiği, fizik muayene bulgularının kaybolduğu görüldü.

Sonuç olarak, omental infarkt iyi huylu, genellikle kendi kendini sınırlayabilen ve nadir görülen bir akut karın nedeni olarak ayıııcı tanıda düşünülmelidir. USG ve BT'nin kullanıma girmesiyle birlikte artık hastalara daha kolay ve doğru tanı konulabilmektedir. Olguların çoğu konservatif olarak tedavi edilebildiğinden doğru tanı gereksiz cerrahi girişimleri de önleyecektir.

\section{KAYNAKLAR}

1. Yıldız S, Atasoy C, Yazıcı C, Akyar S. Omental infarction: CT findings (case report).[Article in Turkish] Tani Girisim Radyoloji 2004; 10:158-61.

2. Aydoğan F, Özbayrak M, Aydoğan $T$, et al. Omental infarction: case report. Turk J Emerg Med 2008;8:181-3.

3. Helmrath MA, Dorfman SR, Minifee PK, et al. Right lower quad rant pain in children caused by omental infarction. Am J Surg 2001;182:729-32

4. Sözen S, Dölalan \$̧, Yıldız F, Elkan H. Primary omental torsion as a cause of acute abdomen: Case report. Ulus Travma Acil Cerrahi Derg 2011;17:554-6.

5. Buell KG, Burke-Smith A, Patel V, Watfah J. Omental infarction: The great impersonator. Cureus 2017;9: e1940.

6. Schwartzman GJ, Jacobs JE, Birnbaum BA. Omental infarction as a delayed complication of abdominal surgery. Clin Imaging 2001;25:341-3.

7. Lindley SI, Peyser PM. Idiopathic omental infarction: One for conservative or surgical management? J Surg Case Rep 2018;2018:rjx095.

8. Bachar GN, Shafir G, Postnikov V, et al. Sonographic diagnosis of right segmental omental infarction. J Clin Ultrasound 2005;33:769.

9. van Breda Vriesman AC, de Mol van Otterloo AJ, Puylaert JB. Epiploic appendagitis and omental infarction. Eur J Surg 2001;167:7237.

10. Puylaert JB. Right-sided segmental infarction of the omentum: clinical, US, and CT findings. Radiology 1992;185:169-72. 